\title{
Nytt steroidkort ved binyrebarksvikt
}

\begin{abstract}
Akutt binyrebarksvikt kan få en dødelig utgang dersom akuttbehandling med kortikosteroider og væske ikke gis raskt. Det nye nasjonale steroidkortet er ment å gi leger enkel og essensiell informasjon om tiltak ved akutt binyrebarksvikt. Forhåpentligvis vil kortet bli godt kjent, slik at både voksne og barn kan få rask og trygg behandling og dødsfall unngås.
\end{abstract}

Akutt binyrebarksvikt eller addisonkrise er en livstruende tilstand. Tilstanden kan oppstå både hos pasienter med primær svikt (mangel på adrenokortikotropt hormon (ACTH)) og krever umiddelbar behandling (1). Det kliniske bildet, karakterisert av en ekstrem sykdomsfølelse, dehydrering og hypotensjon med natriummangel, er spesielt uttalt ved den primære formen, siden disse pasientene også mangler aldosteron. Kraftige magesmerter er vanlig og kan forveksles med akutte kirurgiske buktilstander. Spesielt barn kan ha hypoglykemi $(1,2)$.

I en norsk mortalitetsstudie av Addisons sykdom hos voksne (3) var ikke totaldødeligheten signifikant økt blant pasientene, men vi så en fordoblet mortalitet hos yngre menn. Av dødsårsakene dominerte Addisons sykdom, infeksjoner og plutselig død. I alle disse kategoriene var akutt binyrebarksvikt sannsynligvis medvirkende til utfallet. En mortalitetsstudie utført i Sverige basert på det nasjonale sykehusregisteret, tyder på en fordoblet mortalitet (4). En tysk studie viste at akutt binyrebarksvikt er vanlig blant binyrebarksviktpasienter, med 6,3 akuttinnleggelser per 100 pasientår (2). De vanligste årsakene var infeksjonssykdommer med diaré og oppkast siden pasientene i denne situasjonen ikke klarer å ta til seg eller beholde sine medikamenter.

\section{Patogenese}

Primær binyrebarksvikt (Addisons sykdom) oppstår når binyrebarken ikke kan produsere tilstrekkelig kortisol og aldosteron. Ved primær svikt sitter feilen i binyrebarken. Enten er det en destruksjon av barkvevet grunnet inflammasjon, infeksjon, blødning eller malign infiltrasjon, eller en genetisk defekt i steroidbiosyntesen. De vanlige årsakene er autoimmunitet (5) og defekt 21-hydroksylaseaktivitet (6), som er den hyppigste årsaken til medfødt binyrebarkhyperplasi. Sekundær binyrebarksvikt skyldes mangel på adrenokortikotropt hormon, enten fordi produksjonen er kompromittert i hypofysen (for eksempel hypofysetumor) eller fordi produksjonen er hemmet grunnet farmakologisk glukokortikoidbehandling.

\section{Behandling og informasjon ved binyresvikt}

Binyrebarksvikt behandles med nær fysio-

logiske doser av glukokortikoider. Ved (Addisons sykdom) og sekundær binyrebark-

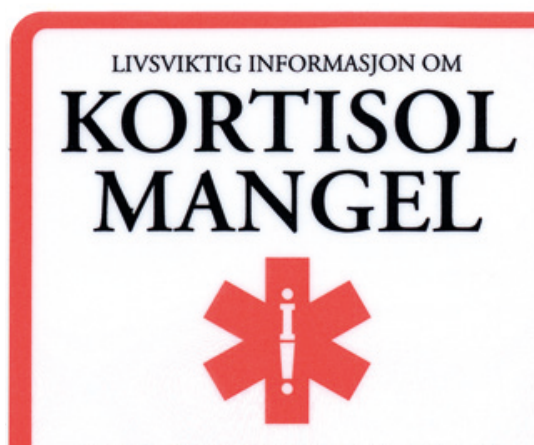

DENNE PASIENTEN TRENGER DAGLIG ERSTATNINGSBEHANDLING MED KORTISON.

Ved feber, oppkast, diaré eller annen større påkjenning, f eks operasjon, infeksjon eller større ulykke må tilførselen av kortison økes.

Ved feber over $38^{\circ} \mathrm{C}$ - ta dobbel dose kortison.

Om oppkast/diaré gjør at tablettene ikke beholdes - oppsøk lege snarest for umiddelbar tilførsel av Solu-Cortef $100 \mathrm{mg}$ iv/im og saltvannsinfusjon.

$$
\text { Norsk endokrinologisk forening }
$$

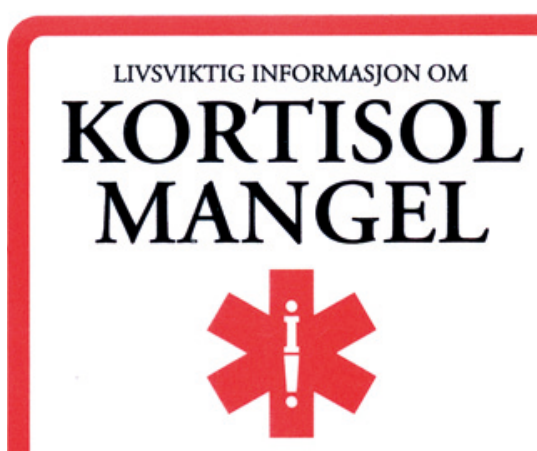

DENNE PASIENTEN TRENGER DAGLIG ERSTATNINGSBEHANDLING MED KORTISON

Ved sykdom eller annen større påkjenning,

f eks operasjon, infeksjon eller større ulykke må tilførselen av kortison økes.

Ta 3 ganger døgndosen fordelt på 4 doser (hver 6. time).

Om oppkast/diaré gjør at tablettene ikke beholdes oppsøk lege snarest for umiddelbar tilførsel av Solu-Cortef $50 \mathrm{mg}$ ( $<5$ år) eller $100 \mathrm{mg}$ ( $>5$ år) iv/im og saltvannsinfusjon.

Norsk endokrinologisk forening

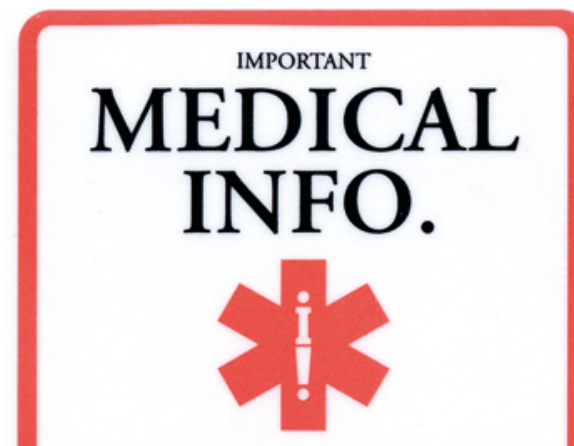

THIS PATIENT NEEDS DAILY REPLACEMENT THERAPY WITH CORTISONE.

In the event of serious illness, vomiting or diarrhoea, hydrocortisone $100 \mathrm{mg}$ iv/im and saline infusion should be administered without delay.

The Norwegian Endocrine Society

\section{Navn / Name}

Personnummer / Date of birth IMPORTANT

\section{MEDICAL INFO.}

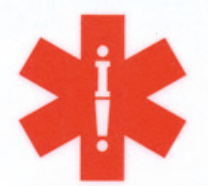

THIS PATIENT NEEDS DAILY REPLACEMENT THERAPY WITH CORTISONE.

In the event of serious illness, vomiting or diarrhoea, hydrocortisone $50 \mathrm{mg}$ ( $<5$ years) or $100 \mathrm{mg}$ ( $>5$ years) iv/im and saline infusion should be administered without delay. The Norwegian Endocrine Saciety
Figur 1 Nasjonale steroidkort for voksne (a) og barn (b). Kortene kan bestilles fra forfatterne. Kortene er utarbeidet med støtte av prosjektmidler fra Helsedirektoratet b 


\section{Ramme 1}

Akutt binyrebarksvikt må mistenkes i følgende situasjoner:

- Akutt sykdom hos pasient med kjent primær eller sekundær binyrebarksvikt

- Akutt sykdom hos pasient som bruker glukokortikoider tilsvarende $>10 \mathrm{mg}$ prednisolon per dag $>3$ uker

- Pasient med sepsis og sirkulasjonssjokk som ikke responderer adekvat på behandling

- «Uforklarlig» hypotensjon gjerne i kombinasjon med hyponatremi

Kliniske karakteristika er: Hypotensjon og ortostatisme, dehydrering, hypoglykemi, kvalme, brekninger, magesmerter, ofte feber, konfusjon, koma. Hyperpigmentering indikerer primær binyrebarksvikt, men må ikke være til stede

Akuttbehandling gis på klinisk indikasjon, ikke vent på prøvesvar:

- Kortisolbehandling til voksne: $100 \mathrm{mg}$ hydrokortison intravenøst lintramuskulært) som bolusinjeksjon hver 6 . time det 1. døgnet (f.eks. Solu-Cortef). Deretter peroral behandling forslagsvis $50+25+25 \mathrm{mg}$ kortisonacetat avtrappende til vedlikeholdsdose over tre døgn

- Kortisolbehandling til barn: $50 \mathrm{mg}$ lalder < 5 år) eller 100 mg lalder > 5 år) hydrokortison intravenøst lintramuskulært) som bolusinjeksjon (f.eks. Solu-Cortef). Deretter gis samme dose som infusjon over 24 t. Nedtrapping og overgang til peroral behandling vurderes individuelt

- Væskebehandling til voksne: $0,9 \% \mathrm{NaCl}$, rask intravenøs infusjon av 1-3 $\mathrm{l}$. Mengden justeres etter blodtrykk og hydreringsgrad. Ved lavt blodsukker gis også glukoseløsning $50 \mathrm{mg} / \mathrm{ml}$.

- Væskebehandling til barn: Følg prosedyre for væskebehandling ved dehydrering og sirkulasjonssjokk. Følg S-glukose, da det er fare for hypoglykemi.

- Behandle eventuelle utløsende årsaker

primær binyrebarksvikt gis i tillegg fludrokortison, som er viktig for vann- og saltbalansen. Manglende binyrebarkfunksjon fordrer at pasienten selv øker kortisondosen $i$ stressituasjoner. Ved feber anbefales en dobling eller tredobling hos voksne pasienter, mens barn anbefales å ta tredobbel døgndose fordelt på fire doseringstilfeller. Skjer ikke det, kan en akutt binyrebarksvikt oppstå. Hos noen pasienter kan selv ufarlige virussykdommer føre til livstruende binyrebarksvikt, spesielt ved oppkast og diaré (2). Vi anbefaler derfor å utstyre pasientene med Solu-Cortef til intramuskulær injeksjon i akuttsituasjoner for å vinne tid til å tilkalle lege (1) (ramme 1). Oftest må pasienten innlegges i sykehus for behandling.

Det er behandlende leges ansvar ikke bare å gi informasjon om akuttbehandling i ulike situasjoner, men også forsikre seg om at pasienten har forstått informasjonen. Til hjelp finnes en norsk pasientforening (7) og et årlig pasientkurs om binyrebarksvikt ved Læringsog mestringssenteret ved Haukeland universitetssykehus. Påmelding skjer via henvisning fra fastlege til Medisinsk avdeling.

\section{Nasjonalt steroidkort for binyrebarksvikt}

Pasientene opplever regelmessig at de ikke blir tatt på alvor selv om de informerer om diagnosen og nødvendig akuttbehandling (8). I dag finnes en rekke informasjonskort ved binyrebarksvikt. Noen er hjemmelaget på ulike sykehus, andre er produsert av pasientforeninger og farmasøytiske firmaer. Sverige innførte i 2011 et nasjonalt steroidkort ved binyrebarksvikt (9), og nå har Norsk endokrinologisk forening besluttet å benytte det samme kortet i Norge med egne versjoner for voksne og barn (fig 1). Kortet er av plast i kredittkortstørrelse med norsk og engelsk tekst og gir enkel og essensiell informasjon til helsepersonell som møter pasienten i en akuttsituasjon. Vi oppfordrer leger og pasienter til å ta kortet i bruk, slik at det blir kjent i hele landet og kan bidra til å sikre rask og korrekt behandling for alle binyrebarksviktpasienter.

\section{Eystein Sverre Husebye \\ eystein.husebye@med.uib.no \\ Martina Moter Erichsen \\ Anne-Grethe Myhre \\ Heiko Bratke \\ Anders Palmstrøm Jørgensen \\ Per Dahlqvist \\ Kristian Løvås}

Eystein S. Husebye (f. 1961) er spesialist $i$ endokrinologi og indremedisin. Han er professor ved Institutt for indremedisin, Universitetet i Bergen, overlege ved Haukeland universitetssykehus og leder for Register for organspesifikke autoimmune sykdommer og den nasjonale studiegruppen for Addisons sykdom. Forfatter har fylt ut ICMJE-skjemaet og oppgir ingen interessekonflikter.

Martina Moter Erichsen (f. 1960) er spesialist i endokrinologi, indremedisin og immunologi og transfusjonsmedisin. Hun er ph.d., overlege ved Medisinsk avdeling, Haukeland universitetssykehus og forsker på Addisons sykdom. Forfatter har fylt ut ICMJE-skjemaet og oppgir ingen interessekonflikter.

Anne-Grethe Myhre (f. 1959) er dr.med., spesialist i barnesykdommer med spesialkompetanse i pediatrisk endokrinologi og overlege ved Barneavdelingen, Oslo universitetssykehus. Forfatter har fylt ut ICMJE- skjemaet og oppgir følgende interessekonflikter: Hun har mottatt reisestøtte fra Pfizer.
Heiko Bratke (f. 1971) er spesialist i pediatri, med spesialkompetanse i pediatrisk endokrinologi og diabetologi. Han er seksjonsoverlege ved Barneavdelingen, Haugesund sjukehus og leder $\mathrm{i}$ interessegruppe for barneendokrinologi. Forfatter har fylt ut ICMJE-skjemaet og oppgir følgende interessekonflikter: Han sitter i styret i Lilly, Medtronic og har mottatt honorar fra Pfizer for arbeid med nasjonalt endokrinologisk symposium.

Anders Palmstrøm Jørgensen (f. 1965) er spesialist $\mathrm{i}$ indremedisin og endokrinologi og er overlege ved Seksjon for spesiell endokrinologi, Oslo universitetssykehus, Rikshospitalet, ph.d.-kandidat og leder i Norsk endokrinologisk forening.

Forfatter har fylt ut ICMJE-skjemaet og oppgir ingen interessekonflikter.

Per Dahlqvist (f. 1970) er dr.med. og spesialist i indremedisin og endokrinologi ved Norrlands universitetssjukhus - Medicincentrum Umeå. Han er medlem av styringsgruppen for det Svenske Addisonregisteret.

Forfatter har fylt ut ICMJE-skjemaet og oppgir ingen interessekonflikter.

Kristian Løvås (f. 1968) er spesialist $i$ indremedisin og endokrinologi og er overlege ved Medisinsk avdeling. Haukeland universitetssykehus og førsteamanuensis ved Institutt for indremedisin, Universitetet i Bergen.

Forfatter har fylt ut ICMJE-skjemaet og oppgir ingen interessekonflikter.

\section{Litteratur}

1. Husebye ES, Løvås K, Allolio B et al. Guidelines on the diagnosis, treatment and follow-up of patients with primary adrenal insufficiency. J Internal Medicine 2012; akseptert for publisering.

2. Hahner S, Loeffler M, Bleicken B et al. Epidemiology of adrenal crisis in chronic adrenal insufficiency: the need for new prevention strategies. Eur J Endocrinol 2010; 162: 597-602.

3. Erichsen MM, Løvås K, Fougner KJ et al. Normal overall mortality rate in Addison's disease, but young patients are at risk of premature death. Eur J Endocrinol 2009; 160: 233-7.

4. Bensing S, Brandt L, Tabaroj F et al. Increased death risk and altered cancer incidence pattern in patients with isolated or combined autoimmune primary adrenocortical insufficiency. Clin Endocrinol (Oxf) 2008; 69: 697-704

5. Erichsen MM, Løvås K, Skinningsrud $B$ et al. Clinical, immunological, and genetic features of autoimmune primary adrenal insufficiency: observations from a Norwegian registry. J Clin Endocrinol Metab 2009; 94: 4882-90.

6. Nermoen I, Brønstad I, Fougner K et al. Genetic, anthropometric, and metabolic features of adult Norwegian patients with 21-hydroxylase deficiency. Eur J Endocrinol 2012; e-publisert 16.7.2012.

7. Morbus Addison foreningen. www.addison.no (10.9.2012).

8. Aas TH. Rapport fra Addison-pasientens verden. Tidsskr Nor Lægeforen 2010; 130: 475.

9. Dahlqvist $P$, Bensing $S$, Ekwall $O$ et al. Nytt nationellt kort vid binjurebarkssvikt. Nytt varningskort kan leda till bättre handläggning och ökad patientsäkerhet. Läkartidningen 2011; 108: 2226-7.

Mottatt 24.8. 2012, første revisjon innsendt 30.8 . 2012, godkjent 6.9. 2012. Medisinsk redaktør Kristin Viste. 